cultural milieu of seventeenth-century England in which translations of the Bible were undertaken. Focusing on the same century, Sarah Rivett's essay shifts attention to the practice of translation as an instrument of conversion of some of the indigenous communities in England's early Atlantic colonies in North America. Carla Nappi's beautifully written chapter revealing the philological, cultural, and embodied practices that took place at the imperial Translators' College (207) in China from the sixteenth to the eighteenth century represents a significant shift in the volume; a world outside Europe is considered in her examination of Chinese-Arabic-Persian translation miscellanies. Line Cottegnies's subject is the cultural and philological practice of translation, into English, focusing on Katherine Philips's translation of Corneille's play La Mort de Pompée. The book's last essay is László Kontler's examination of the complexities of cross-cultural, Scottish-German contact by way of translation, in an assessment of a Scottish historiography of eighteenth-century Germany. The coda is written by a translator from Spanish, Edith Grossman, revealing not only much that readers would like to know about "translation [as] a strange craft" (250) by an award-winning practitioner of that strangeness, but even more about the difficulties of rendering one language-with its unique philology and culture-into another.

The quality of argument, the extensive archive of generically different texts, and the breadth of methodological approaches, together with the lucidity of analysis, assure me that this book will have a long shelf life.

GORAN STANIVUKOVIC

Saint Mary's University, Halifax

\title{
O'Brien, Emily.
}

The Commentaries of Pope Pius II (1458-1468) and the Crisis of the FifteenthCentury Papacy.

Toronto: University of Toronto Press, 2015. Pp. xiii, 335. ISBN 978-1-44264763-3 (hardcover) \$65.

As a text, The Commentaries of Pope Pius II is one of the richest sources for studies on fifteenth-century intellectual culture. Written by Pope Pius II (born Aeneas Sylvius Piccolomini) from 1462 until his death in 1464, The 
Commentaries is filled with anecdotes, portraits of people, politics, and states, and descriptions of rituals and cultural processes. Written from a humanist perspective, it provides a rich historical background that furnishes elaborate descriptions of European and Church history during Piccolomini's lifetime. An unwieldy document as a whole, The Commentaries in its twelve (or thirteen) books presents a challenge to historians: while The Commentaries is useful to the historian for mining anecdotal and intellectually rich examples of fifteenthcentury life, how can we understand a source so fragmented in its anecdotes and narratives and so given to artful and rhetorical showmanship that it is difficult to take literally or to understand as a whole?

In her book, Emily O'Brien presents a clear and straightforward argument to give historians an answer: Pius II wrote his Commentaries as an apologia for his own papacy and for the papal monarchy as an institution. While it is widely accepted that Pius's text has a strong political slant, and that Pius wrote The Commentaries to bolster his own papacy, O'Brien's analysis goes further: she situates The Commentaries as a whole, and its authorship, among the multiple crises facing the Renaissance Papacy. This is no easy feat. Putting The Commentaries together with every document, public and private, that Pius II wrote both before and after his elevation (letters, other books, and papal bulls, among many others), O'Brien argues that in writing his text, Pius II systematically engaged with conciliar, papal, and humanist politics and writings. O'Brien thus suggests that The Commentaries was meant to address and rewrite the historical truth of Pius's papacy, and to respond to "the crisis of temporal and spiritual authority in which he and the papacy were immersed" (13). O'Brien argues for the apologetic nature of Pius's Commentaries, but then goes to show how Pius worked to craft his Commentaries in a deeply investigative way.

A book of six chapters, O'Brien's work is further divided into two discrete sections. Chapters 1 to 3 situate the intellectual and political climates that Pius II participated in and wrote for: the conciliar crises facing the fifteenthcentury Church and papacy, the growing authority of secular princes working against the popes, and the secularizing image of the papacy as a political power in Italy and the response of the Italian lords are all worlds in which Pius II developed intellectually and in which he actively participated. Chapters 4 through 6 provide an in-depth methodological analysis of The Commentaries, highlighting the themes showing up in Pius's work, his writing style, and his 
historical approach as a narrative author and humanist. The chapters show how Pius's political stances influenced his authorship, from his earlier histories to The Commentaries, his magnum opus. The first section lays out, in great detail, the instabilities facing the church and papacy in fifteenth-century Europe; the second section links to the first by outlining precisely how Pius responded to the instabilities. Treating The Commentaries as a historical text and situating it among the methods and type of history written by other humanists in the 1400s, O'Brien describes in great detail how and why Pius II authored his memoirs as he did, and gives readers a full contextualization of The Commentaries as an inherently political and historical text.

O'Brien does a very convincing job of presenting The Commentaries as an apologetic historical text, but her argument approaches Pius at face value as a politically-minded author. While The Commentaries fits beautifully into her argument for Pius writing humanist historiography used for political purposes, it was also a creatively authored text, copying from multiple ancient sources (sometimes word for word) and imparting an image of Pius that, while political, was also artistic; The Commentaries presents its author as an intellectual, who hides behind the rhetoric of humanist posturing and narrative. While O'Brien very ably discusses the edited and then re-written Pius from a political perspective, she rarely addresses this other side to his work. A discussion concerning Virgilian and Caesarean imitation in The Commentaries focuses on the nature of authority and monarchy of an emperor (and therefore, pope), but leaves aside the artistic nature of Pius's imitation, where his use of Juvenal, Virgil, and Caesar served not only to bolster his authority and stances but also to artistically flourish and enhance his stories. O'Brien therefore treats The Commentaries almost singularly as a political piece; while she recognizes the document's subtlety and artistry, her reading of Pius's authorship is only from a political stance.

But none of this is meant to detract from what O'Brien has accomplished. As she noted in the preface, scholars of fifteenth-century humanism, the late medieval church, and the political and cultural life of the 1400s have been missing a concrete understanding of Pius's Commentaries as an entire document. O'Brien's work on Pius and The Commentaries, with its clear thesis for a papal apologia in a very political climate, is filled with a remarkable amount of information and analysis. She provides a very useful summary and discussion of fifteenth-century theological and ecclesiastical politics along 
with a concrete understanding of Italian politics in the mid 1400s. She situates Pius's other writings alongside The Commentaries, and creates an intellectual history of Pius's own political thinking and its development. Moreover, she gives us an important and deeply contextualized interpretation of one of the most important humanist texts of the mid-fifteenth century. She should be commended for her work.

BARRY TORCH

York University

\section{Olds, Katrina B.}

\section{Forging the Past: Invented Histories in Counter-Reformation Spain.}

New Haven, CT: Yale University Press, 2015. Pp. xiii, $422+2$ maps. ISBN 9780-300-18522-5 (hardcover) US\$65.

With this ground-breaking book, Katrina Olds delves into a long-neglected and under-appreciated area of Spanish Golden Age scholarship: antiquarianism. It requires a fair bit of courage and a great deal of perseverance-the author herself might call it masochism - to plough through endless volumes of verbose Latin prose to extract meaningful information about the intellectual practices and learned disputes of sixteenth- and seventeenth-century Spanish erudites. But this thankless task has borne fruit. Fortunately for her readers (and for herself, we might add), Olds has chosen to approach her subject through the controversial and tantalizing figure of the Toledan Jesuit Jerónimo Román de la Higuera, the (in)famous creator of several "false chronicles" on early Spanish Christian saints. Written in a lively and engaging manner, Forging the Past explores the role of fiction and forgery in early modern religious history by taking its authors seriously instead of merely dismissing them as most critics have done up to now. Going back to their medieval origins, the book shows how such falsifications were actually quite common and very often accepted as true, whether out of interest or genuine piety and devotion. As Olds demonstrates through her nuanced study of the uses of the past in Renaissance Spain, myths and legends were fundamental to early modern people's sense of self and their sense of place in space and time. Uncertainties about sources seemed to evaporate when it came to questions of local or national identity. 